KS. GRZEGORZ LESZCZYŃSKI

Wydział Prawa i Administracji Uniwersytetu Łódzkiego

ORCID 0000-0003-4189-5165

\title{
KONCEPCJA NALEŻYTEJ WOLNOŚCI KONIECZNEJ DO PRZYJĘCIA ŚWIĘCEŃ
}

Treść: Wstęp. - 1. Motywacja. - 2. Osąd przedmiotu. - 3. Swobodny wybór. - 4. Wypełnienie decyzji. - Wnioski.

\section{Wstęp}

Prawodawca w kan. 1026 Kodeksu Prawa Kanonicznego stwierdza, iż wyświęcić można tylko tego, kto cieszy się należytą wolnością ${ }^{1}$. R. Zavalloni wskazuje na cztery podstawowe elementy każdej wolnej decyzji człowieka. Są to: motywacja, osąd, wybór i realizacja podjętej decyzji. Motywacja wskazuje faktory i przyczyny, które mają wpływ na proces dokonywania wyboru. Osąd uaktywnia proces dyskusyjny dokonujący się w podmiocie, który opiera się na ocenie poszczególnych możliwości z uwzględnieniem konkretnych wątpliwości, argumentów za i przeciw. Decyzja, czyli wybór w ścisłym tego słowa znaczeniu oznacza akt, na mocy którego podmiot zajmuje określoną pozycję w odniesieniu do motywów i różnych argumentów. Wypełnienie decyzji, czyli jej realizacja jest dopełnieniem procesu decyzyjnego, choć w ścisłym sensie do niego nie należy².

\footnotetext{
${ }^{1}$ Kan. 1026 KPK: „Ut quis ordinetur debita libertate gaudeat oportet...”.

${ }^{2}$ Por. R. Zavalloni, La libertà personale. Psicologia della condotta umana, Milano 1973, s. 85-86.
} 


\section{Motywacja}

Spośród wyżej wskazach elementów określających każdą wolną decyzję człowieka najważniejszym jest motywacja. Od motywacji zależy w sposób bezpośredni każda decyzja. Każda decyzja opiera się, bowiem na określonych motywach. Czynimy coś, ponieważ uważamy, że istnieją racje skłaniające nas do podjęcia określonego działania. Dokonujemy takiego a nie innego wyboru, ponieważ uznajemy coś za rzecz wartą uwagi, ważną albo przyjemną. Każdy akt ludzki jest, zatem oparty na określonych motywach ${ }^{3}$.

R. DeCharms próbując określić motywację stwierdza, iż jest ona czymś w rodzaju łagodnej formy obsesji ${ }^{4}$. Motywacja, bowiem sprawia, że ktoś, kto ma pewien cel, wytęża siły i trwa przy tym celu nie odwracając od niego uwagi. Motywacja nie jest jakąś homogeniczną jednością, ale jak podkreśla $\mathrm{z}$ kolei $\mathrm{F}$. Rheinberg, jest tworem abstrakcyjnym, z którego pomocą spośród wielu różnych życiowych procesów wyodrębnia się i rozważa te, które pozostają w związku $\mathrm{z}$ wytrwałym ukierunkowaniem naszego zachowania na pewien $\mathrm{cel}^{5}$.

Każdy akt ludzki ma swój motyw. Człowiek czyni coś, ponieważ uważa, że są motywy, dla których winien to uczynić. Motywem zatem można określić każdy faktor, który skłania człowieka do podjęcia określonej decyzji. Motyw jednak nie jest tym samym, co motywacja. Motyw staje się motywacją, gdy podmiot czyni z niego przyczynę swojego działania, a zatem zachodzi relacja między motywem a podmiotem. Należy, bowiem zauważyć, że w wolnym działaniu człowieka nie zawsze najistotniejsze stają się motywy najsilniejsze, gdyż w rzeczywistości to konkretna osoba decyduje o tym czy jest w stanie oprzeć się różnym motywom i nad nimi zapanować czy też nie. Co więcej to konkretna osoba decyduje czy jakiś motyw stanie się dla niej przyczyną działania czy też nie.

\footnotetext{
${ }^{3}$ Por. G. Zuanazzi, Libertà come destino, Roma 2001, s. 11.

${ }^{4}$ Por. R. DeCharms, Enchancing motivation: Change in the classroom, New York 1979, s. 55.

${ }^{5}$ Por. F. Rheinberg, Psychologia motywacji, Kraków 2006, s. 17.
} 
Należy w tym miejscu dokonać rozróżnienia między motywami działania a przyczynami tegoż działania. Motywy wprawdzie usprawiedliwiają podjęcie decyzji, ale nie zmuszają człowieka do jej podjęcia. Motywy stają się przyczynami działania, o ile zostaną uznane jako takie przez człowieka. W tym sensie przyczyny, które decydują o ludzkim działaniu, mają wpływ na końcową decyzję podmiotu. Można by zatem postawić tezę, że w jakimś sensie determinują one podmiot do podjęcia określonej decyzji. Można by też, spoglądając na tę kwestię w innym świetle stwierdzić, że wpływ motywów na końcową decyzję podmiotu jest niewielki.

Wolność działania nie może być interpretowana jako pozbawiona jakichkolwiek motywów, wolność pusta czy też abstrakcyjna. Nie należy zatem przeciwstawiać wolności istnieniu motywów działania. Jak słusznie zauważa G. Zuanazzi, wolność realizuje się na płaszczyźnie istnienia motywów działania. Wolność, która nie zderza się z emocjami, pragnieniami, osądami jest wolnością absurdalną i nieistniejącą ${ }^{6}$.

Istnienie motywu lub motywów działania nie niweczy ludzkiej wolności i nie determinuje działania człowieka. Sam motyw bowiem, nie ma mocy wywołania ludzkiego działania, a jedynie może to działanie stymulować. Motyw przedstawia ludzkiej świadomości pewne formy działania jako atrakcyjne lub istotne. W tym jednak względzie czynnik osobisty, związany z osobowością i psychiką człowieka, odgrywa rolę pierwszorzędną. Siła oddziaływania motywów zależy przede wszystkim od struktury psychicznej człowieka. Motyw wskazuje człowiekowi kierunek działania, ale nie determinuje go do działania we wskazanym kierunku. W przypadku osoby zdrowej i niedotkniętej żadnym zaburzeniem psychicznym motywy nigdy nie są na tyle silne by determinować działanie człowieka. Chcenie świadome charakteryzuje się tym, że człowiek panuje nad impulsem i motywem czyniąc z niego przyczynę działania swoją wolną decyzją ${ }^{7}$.

\footnotetext{
${ }^{6}$ Por. G. Zunanazzi, Psycologia e psychiatria nelle cause matrimoniali canoniche, Città del Vaticano 2006, s. 78.

${ }^{7}$ Por. L. Zavalloni, dz. cyt., s. 236.
} 
Problem powstaje wówczas, gdy osoba jest dotknięta silnym zaburzeniem natury psychicznej. W tym bowiem przypadku motywy zaczynają dominować stając się konieczną przyczyną ludzkiego działania. Niweczą one ludzką zdolność do autodeterminacji. Gdy motywy zaczynają decydować o funkcjonowaniu człowieka oznacza to, że nie jest on zdolny z przyczyn związanych z jego psychiką do reakcji i obrony, a zatem do samodzielnej i wolnej decyzji, czyli do autodeterminacji. Nie można zatem mówić o wolności działania wówczas, gdy to motywy determinują koniecznie ludzkie postępowanie. Słusznie więc zauważa G. Zuanazzi, że tam, gdzie jest konieczność, nie ma wolności ${ }^{8}$.

Istnienie motywów nie przeczy, zatem wolności decyzji w przypadku osób zdrowych i takich, u których zaburzenie sfery emocjonalnej lub ogólnie mówiąc psychicznej nie jest na tyle silne, aby determinować działanie człowieka. Nie oznacza to, że motywy nie mają określonego wpływu na decyzję człowieka. Nie do przyjęcia są zatem tezy czasem wypowiadane, że motywy z racji na ich oddziaływanie jedynie w początkowym stadium procesu decyzyjnego nie mają istotnego albo w ogóle nie mają żadnego wpływu na decyzję człowieka. Motywy jakkolwiek nie determinują działania człowieka, to jednak wskazując konkretne przyczyny tegoż działania mają realny wpływ na ludzkie decyzje. Co więcej, nie jest prawdą, że motywy oddziałują jedynie w początkowej fazie decyzyjnej, gdyż w zależności od psychiki człowieka, ich obecność jest stała w trakcie całego procesu poznania, a następnie wyboru określonego przedmiotu.

Motywacja podświadoma, zdaniem S. Freuda, jest prawdziwą rzeczywistą motywacją ludzkiego działania. Motywacja ta tworzy bowiem motywy, które człowiek pozornie uznaje jako świadome,

\footnotetext{
${ }^{8}$ Por. G. Zuanazzi, Psicologia, dz. cyt., s. 79. Autor stwierdza: „La libertà vive sicuramente nell'orizzonte della coscienza, implica la consapevolezza dell'atto, del che cosa voglio e del perché. Il sapere però non è tutto; se così fosse, la libertà sarebbe già perduta in partenza, soffocata dalla necessità della ragione. Sono libero quando seguo le mie ragioni ...per scegliere una cosa piuttosto che un'altra, per acconsentire ad un progetto che nasce dalla mia esperienza esistenziale, per decidermi in un senso o in un altro".
} 
twierdząc, że jest panem własnego Ja. W rzeczywistości to podświadome motywy naszego działania tworzą przyczyny, które skłaniają nas do podejmowania określonych decyzji ${ }^{9}$. Jakkolwiek nie ma żadnych naukowych dowodów na prawdziwość tak jednoznacznie sformułowanej tezy, niezaprzeczalne jest, że podświadomość i to wszystko, co z sobą niesie, mają znaczący wpływ na procesy ludzkich decyzji i wyborów ${ }^{10}$.

Motywacja podświadoma, jak określa ją M.F. Pompedda, opiera się na szeregu pojęć, wrażeń, wspomnień, tendencji, kompleksów, uzależnień, które w sposób znaczący ingerują w wolną wolę osoby i wpływają na podejmowaną przez nią decyzję. Należy mieć tu na względzie zarówno impulsy, które wynikają z głębokich przeżyć emocjonalnych okresu dzieciństwa, młodości, jak i innych przeżyć, które pozostawiły swój ślad w podświadomości człowieka, pomimo że wydarzenia te nie istnieją już w jego pamięci ${ }^{11}$.

W sytuacji normalnej wszystkie podświadome motywy w jakimś sensie i w jakimś stopniu warunkują decyzję człowieka. Nigdy jednak jej nie determinują pozostawiając człowiekowi wolność dokonania wyboru. Jak zauważa R. Zavalloni, motywy te nigdy nie osiągają poziomu motywów świadomych, a ich wpływ na decyzję małżeńską ma charakter jedynie pewnych ograniczeń i uwarunkowań ${ }^{12}$.

\footnotetext{
${ }^{9}$ Por. S. Freud, Opere, t. 8, Introduzione alla psicoanalisi, Torino 1976, s. 446.

${ }^{10}$ Por. J. Van Rillaer, Les illusions de la psychanalyse, Bruxelles 1980, s. 280-281.

${ }^{11}$ Por. G. Zuanazzi, Psicologia, dz. cyt., s. 87. Czytamy tutaj: „Non importa che la motivazione cosciente sia legata a questa o a quella esperienza ormai dimenticata, a questo o a quel bisogno incoscio; non importa l'origine della motivazione consapevole; conta invece la possibilità di confrontare tale motivazione, così com'è vissuta, con la regola architettonica della vita, con il progetto esistenziale”.

${ }^{12}$ Por. R. Zavalloni, dz. cyt., s. 257. Ten ostatni stwierdza: „Questi motivi non determinano propriamente la condotta umana; essi la condizionano soltanto. Tutti questi fattori, come la suggestione, i bisogni incoscienti, l'eredità e l'ambiente, ivi comprese la costituzione fisiologica e la condizione patologica di una persona, possono essere considerati come gli elementi della sua motivazione nel senso largo della parola; nella misura in cui essi influenzano l'attività dell'uomo, senza raggiungere il livello di coscienza, costituiscono ciò che può essere detto il condizionismo o le limitazioni della libertà umana”.
} 
W rzeczywistości, bowiem, co podkreśla L.M. Rulla, człowiek pozostaje wolny, pomimo swojej przeszłości i podświadomości ${ }^{13}$.

\section{Osąd przedmiotu}

Motywy mają swoje znaczenie w odniesieniu do czynności poznawczych podmiotu, a w konsekwencji do dokonywanego przez rozum praktyczny osądu. Czynności te oparte są bowiem na motywach, zarówno świadomych, jak i podświadomych, a w konsekwencji w jakimś sensie są nimi uwarunkowane.

Postrzeganie rzeczywistości przez człowieka umożliwia wypracowanie osądu co do przedmiotu poznania. W doktrynie kanonistycznej wyróżnia się dwa kolejne rodzaje poznania, a mianowicie poznanie teoretyczne i poznanie oceniające. Poznanie teoretyczne nie jest wystarczające do tego, aby dana osoba miała konieczną wolność wyrażenia aktu święceń. W tym względzie niezbędne jest też poznanie krytyczne albo inaczej poznanie oceniające odnoszące się zarówno do przedmiotu święceń, jak i wynikających z nich obowiązków. Należy jednak zauważyć, że między poznaniem teoretycznym a poznaniem praktycznym zachodzi relacja podporządkowania oraz współzależności. Podmiot niemający zdolności poznania teoretycznego nie dysponuje również zdolnością poznania oceniającego. Z kolei podmiot mający zdolność poznania oceniającego posiada również zdolność poznania teoretycznego.

\section{Swobodny wybór}

Decyzja opiera się przede wszystkim na wolnej woli człowieka. Wolność ta może mieć różny wymiar. W zależności od przyczyn presji wywieranej na człowieka, wyróżnia wolność fizyczną, moralną, psychologiczną i polityczną.

Św. Tomasz z Akwinu wyróżnia trzy formy wolności: wolność działania, dokonania wyboru oraz dokonania wyboru dobra lub zła. Pierwsza z tych form pozwala człowiekowi działać lub zaniechać

${ }^{13}$ Por. L.M. Rulla, Antropologia della vocazione cristiana, t. 1, Basi interdisciplinari, Bologna 1997, s. 186-187. 
działania. Druga pozwala w odniesieniu do danego przedmiotu dokonać wyboru działania dla określonego celu lub nie. Trzecia forma wolności pozwala dokonać wyboru działania ukierunkowanego na dobro lub na $\mathrm{złoO}^{14}$.

Wolność, z punktu widzenia filozofii, oznacza niezależność człowieka w podejmowaniu konkretnych decyzji. Oznacza, że osoba wolna w momencie dokonywania wyboru jest w stanie podążać $\mathrm{w}$ stronę określonego celu, jakim jest dobro ${ }^{15}$.

Z punktu widzenia psychologii wolność umożliwia człowiekowi podjęcie przez niego decyzji, czyli dokonanie wyboru. Wybór ten $z$ kolei jest możliwy, o ile dana osoba jest osobą wolną. Wolność zatem nie jest tym samym, co akt dokonania wyboru. Dokonanie wyboru

${ }^{14}$ Por. Thomas Aquinas, De veritate, q. 22, a. 6. Czytamy tutaj: „....libertas voluntatis in tribus considerabitur: scilicet quantum ad actum, in quantum potest velle hoc vel illud, etiam eius oppositum; et quantum ad ordinem finis, in quantum potest velle bonum vel malum. Sed quantum ad primum horum inest libertas voluntati in quolibet statu naturae respectu cuiuslibet obiecti. Cuiuslibet enim voluntatis actus est in potestate ipsius respectu cuiuslibet obiecti, secundum vero horum est respectu quorumdam obiectorum, scilicet respectu eorum quae sunt ad finem, et non ipsius finis; et etiam secundum quemlibert statum naturae. Tertium vero non est respectu omnium obiectorum, sed quorumdam, scilicet eorum quae sunt ad finem; nec respectu cuiuslibet status naturae, sed illius tantum in quo natura deficere potest. Nam ubi non est defectus in apprehendendo et conferendo, non potest esse voluntas mali etiam in his quae sunt ad finem, sicut patet in beatis. Et pro tanto dicitur, quod yelle malum nec est libertas, nec pars libertatis, quamvis sit quoddam libertatis signum".

${ }^{15}$ Por. B.J. F. Lonergan, Grazia e libertà, Roma 1970, s. 139-141. Autor tak określa akt wolny z punktu widzenia filozofii: „Un atto libero ha quattro presupposti: A) un campo di azione in cui più di un corso di azione è oggettivamente possibile; B) un intelletto che è capace di elaborare più di un corso di azione; C) una volontà che non è automaticamente determinata dal primo corso di azione che si presenta all"intelletto; e, dal momento che questa condizione è solo una condizione che assicura l'indeterminazione senza però dire donde, di fatto, proviene la determinazione; D) una volontà che muove se stessa ...La prima causa l'oggettiva possibilità di diversi corsi d"azione; la causa seconda è l'intelletto che conosce questa oggettiva possibilità; e la causa prossima è la volontà che sceglie, non perché determinata dall'intelletto, ma mediante la propria automazione". 
jest bowiem aktem, który wymaga od podmiotu koniecznej wolności psychologicznej. Ponadto, wolność z punktu widzenia psychologii jest czymś abstrakcyjnym i w praktyce nie istnieje. Istnieją natomiast osoby, które są wolne i jako takie zdolne do dokonania wyboru.

Osobę można nazwać wolną, jeśli w momencie podejmowania decyzji nie jest uzależniona od takiej choroby, sytuacji czy presji na nią wywieranej, która determinuje jej decyzje i postępowanie. Wolność absolutna oczywiście nie istnieje. Każdy człowiek jest w jakimś sensie uzależniony czy też podlega różnym ograniczeniom ${ }^{16}$. Człowiek jest wolny, ale wolność ta ma zawsze określone granice. Jak zauważa M.F. Pompedda, człowiek nigdy nie jest wolny od swojej natury, seksualności, pasji, afektów, a także swojej historii i miejsca w społeczeństwie. Człowiek nigdy nie będzie wolnym od jego wad, słabości, frustracji, od jego charakteru. Te bowiem faktory decydują o jego substracie psychofizycznym. Nie oznacza to jednak, że niweczą one naturalną zdolność człowieka do autodeterminacji.

Wolność tak rozumiana oznacza, że człowiek jest w stanie uczynić z tego, co dzięki działaniu intelektu uznał za wartość, motyw i przyczynę działania. Stąd wolność wymaga, aby wpływ różnego rodzaju czynników lub faktorów wyżej zauważonych, nie był nigdy na tyle silny, by determinować działanie człowieka ${ }^{17}$. Człowiek jest zdolny do autodeterminacji, o ile zarówno z zewnątrz jak i od wewnątrz, nie jest zmuszony do podjęcia lub zaniechania określanego działania.

${ }^{16}$ Por. M. Merleau-Ponty, Fenomenologia della percezione, Milano 1965, s. 578.

${ }^{17}$ Por. Thomas Aquinas, Summa, I, q. 19, a. 1; q. 59, a. 1. Czytamy tutaj: „Progredientibus scientiis psychologicis ac psychiatricis, quae a Divo Thoma asserta sunt, ae aptius ac penitus dignoscuntur, atque quaenam sint actiones proprie humanae, ex deliberata voluntate procedentes ac libero arbitrio statutae, rectius nostro tempore determinari possunt, ut secernantur ab aliis, quae tantummodo speciem actionum humanarum praebent, sed revera sunt merae actiones hominis, cum ob defectus, quibus persona implicatur, a deliberata voluntate minime procedant. ...Processus psychicus vero ad deliberandum consensum matrimonialem impediri potest psychicis anomaliis, quarum aliquae potius facultatem volitivam quam facultatem intellectivam praepediunt. Quamvis enim intellectus et voluntas in homine unum constituant et ad invicem compleantur, cum omnis substantia intellectualis sit volens". 
Wolność ta, czyli zdolność do autodeterminacji może zostać naruszona poprzez działanie innych osób lub poprzez wpływ czynników zewnętrznych lub uwarunkowań wewnętrznych, zarówno świadomych jak i podświadomych. W sytuacji chorobowej, psychogennej czy patologicznej wpływ tychże elementów pozostaje tak silny, iż stają się one przyczyną i motywem działania, pozbawiając osobę możliwości dokonania wyboru, a zatem autodeterminacji ${ }^{18}$.

Człowiek jako taki nigdy nie jest wolny od różnego rodzaju ograniczeń. Jak zauważa G. Zuanazzi, anormalność jest w pewnym sensie normalnością bytu ludzkiego. Owa anormalność może przybierać różne formy i stopnie nasilenia. W odniesieniu do aktu święceń jako aktu ludzkiego skutek prawny mają jedynie te uwarunkowania, które w sposób patologiczny lub chorobowy pozbawiają człowieka wymaganej wolności do podjęcia tegoż aktu ${ }^{19}$.

Akt przyjęcia święceń jako akt ludzki winien być świadomy i wolny. Oznacza to, że winien być dokonany bez jakichkolwiek nacisków zewnętrznych lub wewnętrznych, które pozbawilyby podmiot zdolności dokonania wyboru i podjęcia decyzji. Idzie tu zarówno o brak przymusu z zewnątrz, jak i konieczną wolność wewnętrzną. Wolność ta oznacza, iż wola jest zdolna do oddalenia wszelkich nacisków wewnętrznych do tego stopnia, że nie determinują one decyzji podmiotu. Człowiek, pomimo swych różnorakich uwarunkowań, pochodzących z wychowania, kultury, środowiska, afektywności, a także podświadomości, jest w stanie podjać decyzję świadomą i rozważną poprzez

\footnotetext{
${ }^{18}$ Por. G. CAnepa, Il concetto di personalità nei suoi aspetti filosofici, biologici e medico-legali, Roma 1953, s. 96-98.

${ }^{19}$ Por. G. Zuanazzi, La capacità intellettiva e volitiva in rapporto al matrimonio canonico: aspetti psicologici e psichiatrici, w: L'incapacità di intendere e di volere nel diritto matrimoniale canonico, Città del Vaticano 2000, s. 308. Autor zauważa: „Una certa anormalità è normale nell'essere umano. Allora l'uomo normale non è l'uomo privo di difficoltà e conflitti, ma quello che ogni giorno accetta consapevolmente la fatica di essere uomo nel tentativo, non mai esauribile, si superare le proprie contraddizioni. Solo i condizionamenti patologici o abnormi, e non qualsiasi fattore che opera al di fuori dell'iniziativa del soggetto e delle sue possibilità di controllo, possono avere rilevanza giuridica".
} 
akt, za który czuje się odpowiedzialny. Człowiek jako istota racjonalna i specyficznie duchowa jest w stanie odnaleźć się wewnętrznie i podjąć choćby z najwyższą trudnością decyzje racjonalne i umotywowane, co do których czuje się autorem. Ta wolność wewnętrzna w praktyce oznacza, że podmiot jest zdolny dokonać wyboru drogi kapłańskiej lub innej drogi życia, dokonać oceny motywów i w sposób wolny podjąć określone działanie.

Akt przyjęcia święceń nie wymaga pełnej wolności osoby, co zresztą nie jest możliwe. Wymaga jedynie takiego stopnia wolności wewnętrznej, który jest proporcjonalny do przedmiotu święceń. Każdy akt ludzki jest aktem woli, ale jako taki wymaga uprzedniego działania intelektu człowieka, zgodnie z zasadą nihil volitum quin praecognitum ${ }^{20}$. Akt przyjęcia święceń będący aktem woli, jak każdy inny akt ludzki, wymaga zatem zaangażowania zarówno woli, jak i intelektu. W procesie decyzyjnym można, więc mówić o współpracy facultas intelectiva oraz facultas deliberativa ${ }^{21}$. Rozróżnienie dokonane między intelektem a wolą człowieka w odniesieniu do aktu, jakim jest akt przyjęcia święceń ma charakter czysto teoretyczny i metodologiczny, gdyż w rzeczywistości psychika każdego człowieka jest jedną i niepodzielną całością. Akt ludzki w swej strukturze jest aktem intelektualno-wolitywnym ${ }^{22}$. Procesy psychologiczne dokonujące się w człowieku, dotyczące sfery intelektualnej i wolitywnej, pozostają ściśle z sobą związane, tak iż ich oddzielenie byłoby sztuczne.

${ }^{20}$ Por. Thomas Aquinas, Summa, dz.cyt., I-II, q. 1, a. 1. Czytamy tutaj: „Dicendum quod actionum quae ab homine aguntur, illae solae propriae dicumtur humanae quae sunt propriae hominis inquantum est homo. Differt autem homo ab aliis irrationalibus creaturis in hoc, quod est suorum actuum dominus. Unde illae solae actions vocantur proprie humanae quarum homo est dominus. Est autem homo dominus suorum actuum per rationem et voluntatem: unde et liberum arbitrium esse dicitur facultas voluntatis et rationis. Illae ergo actions proprie humanae dicuntur quae ex voluntate deliberate procedunt".

${ }^{21}$ Por. C. BARBIERI, La capacità intellettiva e volitiva nell'ambito delle scienze mediche e pisologiche, $\mathrm{w}$ : L'incapacità di intendere e di volere nel diritto matrimoniale canonico, Città del Vaticano 2000, s. 334.

${ }^{22}$ Por. H. BARrois, Die Personalität des Menschen in der Bewertung der neueren kirchlichen Ehegerichtsbarkeit, Freiburg-Basel-Wien 1978, s. 48-49. 
Rozróżnienie jednak pomiędzy rozumem i wolą jest niezaprzeczalne, tak jak odrębne są przedmioty formalne i akty każdej z tych władz. Czym innym jest bowiem esse cognoscibile, czym innym zaś jest bonum seu appetibile ${ }^{23}$. Z punktu widzenia teoretycznego i metodologicznego możliwe jest zatem dokonanie rozdzielenia tych dwóch funkcji psychiki człowieka w celu zobrazowania procesu decyzyjnego.

Nie wystarczy teoretyczne opracowanie intelektu, aby dana osoba podjęła decyzję w sposób odpowiedzialny i wolny. Konieczna w tym względzie jest współpraca wolnej woli człowieka (facultas deliberativa $)^{24}$. Co więcej, ciężar podejmowania konkretnej decyzji nie należy do intelektu, ale jest zadaniem woli człowieka ${ }^{25}$. Jak zauważa L. Zani nie wystarczy wiedzieć jaka winna być decyzja, by rzeczywiście została ona podjęta ${ }^{26}$. To wola dokonuje wyboru poprzez praktyczną ocenę wartości przedmiotu. Co jednak podkreśla K. Jaspers wola jako taka nie może nic stworzyć, ale jedynie podążyć w kierunku czegoś, co istnieje i zostało poznane ${ }^{27}$.

\footnotetext{
${ }^{23}$ Por. V. Remer, Psychologia, Romae 1925, s. 227. Autor pisze: „Aliud enim obiectum est esse cognoscibile, et aliud esse bonum seu appetibile; aliud actus est rem ad se trahere et intentionaliter in anima collocare, et alius in rem se ferre, prout est in rerum natura seu secundum esse reale quod habet".

${ }^{24}$ Por. Thomas Aquinas, Summa, dz. cyt., I-II, q. 9, a. 1. Czytamy tutaj: „Bonum autem in communi, quo habet kationem finis, est obiectum voluntatis. Et ideo ex hac parte voluntas movet alias potentias animae ad suos actos: utimur enim aliis potentiis cum volumes. Nam fines et perfections omnium aliarum potentiarum comprehenduntur sub obiecto voluntatis, sicut quaedam particularia bona".

${ }^{25}$ Por. G. Zuanazzi, Psicologia, dz. cyt., s. 75. Autor zauważa: „Eppure per agire non basta né conoscere né sentire: occorre volere. La volontà va considerata come potere di inibizione e come tecnica di azione. Se il primo manca ha luogo l'azione impulsiva imperiosa e abberrante; se è eccessivo, l'azione diventa impossibile e il soggetto prova un'impressione di irrealtà o si perde nell'esame del pro e del contro. Come tecnica d'azione, la volontà si esprime nell'acconsentire, nello sciegiere e nell'eseguire; perciò, richiede controllo, coerenza, consapevolezza della situazione e capacità di adattamento".

${ }^{26}$ Por. L. ZANi, Psicologia e vita, Milano 1967, s. 58.

${ }^{27}$ Por. K. Jaspers, Psicologia delle visioni del mondo, Roma 1950, s. 419.
} 
Z oczywistych względów trudno mówić o dwóch oddzielonych od siebie i następujących kolejno fazach w procesie decyzyjnym o charakterze intelektualno-wolitywnym. Nie jest bowiem tak, że najpierw intelekt dokonuje poznania przedmiotu, a następnie proponuje woli podjęcie decyzji. Jak zauważa M.F. Pompedda decyzja jest konsekwencją wspólnego działania intelektu i woli, przy zachowaniu charakterystyki poszczególnych funkcji psychiki człowieka.

Św. Tomasz dokonuje rozróżnienia między voluntas ut natura oraz voluntas ut ratio. Ten pierwszy rodzaj woli oznacza naturalną skłonność podmiotu do dobra wyższego, ten drugi zdolność dokonania wyboru ${ }^{28}$. Ponieważ ów wybór polega na podążaniu w kierunku określonego celu, stąd często jest utożsamiany z praktycznym osądem $^{29}$. W rzeczywistości przedmioty działania woli i praktycznego rozumu nie są takie same.

Wola człowieka jest funkcją psychiczną opartą na dokonywaniu wyboru w przypadku działań selektywnych oraz na podążaniu do wskazanego motywem celu w przypadku działań prostych. G. Zuanazzi podkreśla, iż nie należy mylić woli z pragnieniem. Pragnienie bowiem ma charakter spontaniczny, może stać w sprzeczności z moimi ocenami moralnymi i istnieje uniezależnienie ode mnie. W akcie woli jestem obecny bardzo mocno i to ja decyduję o kierunku, w którym podążę, niekoniecznie związanym z samozadowoleniem. Można pragnąć coś, co jest niemożliwe, ale nie można tego wybrać i podążyć w jego kierunku ${ }^{30}$.

Nie należy też utożsamiać woli z działaniem rozumu, który funkcjonuje zgodnie z zasadą wyboru tego, co lepsze i bardziej właściwe. Akt woli, co podkreśla V. Marcozzi, nie jest aktem rozumowym ani prostym odzwierciedleniem działania intelektu, choć jego uprzednie działanie w stosunku do woli jest konieczne. Akt woli jest zatem aktem autonomicznym ${ }^{31}$.

\footnotetext{
${ }^{28}$ Por. Thomas Aquinas, Summa, dz. cyt., III, qq. 18, a. 3.

${ }^{29}$ Por. tamże, I-II, q. 1, a. 7.

${ }^{30}$ Por. G. Zuanazzi, La capacità, dz. cyt., s. 296-297.

${ }^{31}$ Por. V. Marcozzi, Antropologia psicologica, Roma 1978, s. 270.
} 
Wola człowieka sprawuje funkcję kontrolną i decyzyjną w odniesieniu do instynktów, pragnień, ale również wskazać intelektualnych. Właściwie funkcjonująca wola pozwala dokonywać wyborów słusznych, opartych na racjonalnych przesłankach. Wola zaburzona w jakikolwiek sposób albo uniemożliwia podjęcie decyzji albo też pozbawia ją elementów racjonalności.

Należy zauważyć, dotykając jedynie problemu, iż niektóre anomalie wpływają przede wszystkim destrukcyjnie na wolę człowieka pozostawiając jego intelekt nienaruszonym. Stwierdza to jednoznacznie orzecznictwo na przestrzeni lat. Oznacza to, że scholastyczna zasada ubi intellectus, ibi voluntas nie do końca jest prawdziwa, a przynajmniej nie koniecznie sprawdza się w każdym przypadku.

\section{Wypełnienie decyzji}

Wypełnienie przedmiotu aktu uzewnętrznia podjętą decyzję. W jakimś sensie jest zatem logicznym następstwem aktu przyjęcia świeceń, choć w ścisłym sensie nie dotyczy samej decyzji, a więc momentu wyrażenia decyzji. Wypełnienie zobowiązania określonego w przedmiocie święceń wiąże się ściśle z jego podjęciem i podobnie jak poznanie i wybór przedmiotu wymaga od kandydata zdolności psychicznej.

Akt przyjęcia świeceń, będący aktem ludzkim, wymaga od kontrahenta zdolności naturalnej, zwanej inaczej zdolnością psychiczną. Zdolność ta oznacza, iż dana osoba w momencie przyjęcia święceń jest zdolna powziąć decyzję dotyczącą zobowiązań wynikających ze święceń w sposób świadomy i dobrowolny oraz jest zdolna dysponować sobą w odniesieniu do wypełnienia podjętych zobowiązań.

Warto w tym miejscu zwrócić uwagę na podstawowe obowiązki wynikające ze święceń kapłańskich. Podstawowym obowiązkiem każdego kapłana jest dążenie do świętości. Obowiązek ten kapłan może wypełniać w oparciu o różnorodne formy uświęcenia, które przewiduje Kodeks. Są to zarówno obowiązki duszpasterskie, jak i lektura Pisma Świętego, sprawowanie Eucharystii, modlitwa, liturgia godzin, rekolekcje, rozmyślanie, sakrament pokuty, szczególna 
cześć Bogurodzicy Dziewicy czy też wiele innych ${ }^{32}$. Jest obowiązkiem każdego duchownego być posłusznym Papieżowi i własnemu ordynariuszowi, zwłaszcza w kwestiach dotyczących wiary, obyczajów i dyscypliny Kościoła ${ }^{33}$. Obowiązek ten nie ma charakteru moralnego, ale jest obowiązkiem natury prawnej i dotyczy aktów władzy rządzenia i Magisterium ${ }^{34}$.

Każdy kapłan winien też podejmować studia o charakterze ogólnym teologicznym i różne inne formy kształcenia duchownych dbając o swoją permanentną formację intelektualną i duchowąa ${ }^{35}$. Dla przykładu, w odniesieniu do kapłanów inkardynowanych lub pełniących posługę w Archidiecezji Łódzkiej, III Synod tejże archidiecezji wskazał na konkretne rozwiązania służące stałej formacji kapłanów. Formacja ta, która wymaga ciągłego rozwijania w sobie wrażliwości na potrzeby innych, umiejętności prowadzenia dialogu z każdym człowiekiem oraz doskonalenia kultury osobistej, w centrum winna stawiać zawsze codzienną celebrację Eucharystii oraz wierne sprawowanie Liturgii godzin i wypełnianie osobistych praktyk religijnych ${ }^{36}$. Każdy kapłan zobowiązany jest co roku do uczestnictwa w rekolekcjach zamkniętych, skupieniach ogólnodiecezjalnych, dekanalnych i innych ${ }^{37}$.

Bardzo ważnym obowiązkiem służącym uświęceniu kapłana jest zachowywanie przez niego celibatu, wraz z nieustannym dążeniem do zachowania pełnej czystości ${ }^{38}$. Należy zauważyć, że obowiązek celibatu zawiera w sobie zarówno aspekt charyzmatyczny, w którym celibat należy postrzegać jako dar od Boga, jak i aspekt prawny. Nie oznacza on wyłącznie bezżeństwa, ale dotyczy również życia w absolutnej czystości. Małżeństwo zawarte przez duchownego jest nieważne i wywołuje określone prawem skutki karne ${ }^{39}$.

\footnotetext{
${ }^{32}$ Por. kan. 276 KPK.

${ }^{33}$ Por. kan. 273 KPK.

${ }^{34}$ Por. D. Mogavero, I ministri sacri o chierici, w: Il diritto, dz. cyt., s. 115.

${ }^{35}$ Por. kan. 279 KPK.

${ }^{36}$ Por. III Synod Archidiecezji Łódzkiej, Statuty, Łódź 1999, art. 70, 71.

${ }^{37}$ Por. Statuty, art. 72, 73.

${ }^{38}$ Por. kan. 277 KPK.

${ }^{39}$ Por. kan. 1087, $1394 \$ 1$ KPK.
} 
Duchowny winien prowadzić też życie proste, pozbawione próżności, w duchu ubóstwa, otwarte na potrzeby innych oraz diecezji ${ }^{40}$. Obowiązki związane z przebywaniem na terenie własnej diecezji wynikające z pełnionego urzędu jak i z inkardynacji, noszenie określonego przez prawo stroju kościelnego, zgodnie z normami wydanymi przez Konferencję Episkopatu, jak i z uwzględnieniem zwyczaju miejscowego ${ }^{41}$ oraz popieranie pokoju i zgody opartej na sprawiedliwości sprzyja bez wątpienia uświęceniu kapłana oraz pomnaża wydawane przez niego świadectwo ${ }^{42}$.

Kodeks Prawa Kanonicznego formuje też szereg obowiązków o charakterze negatywnym określając co jest zakazane kapłanowi lub czego winien unikać dla bardziej owocnego wypełniania swojej misji. I tak zabrania się kapłanowi wszystkiego, co nie przystoi stanowi duchownemu według przepisów prawa partykularnego ${ }^{43}$. Kapłan natomiast winien unikać tego wszystkiego, co jest obce stanowi duchownemu, choć samo w sobie nie jest nieprzyzwoite ${ }^{44}$, w tym przyjmowania publicznych urzędów i wykonywania władzy świeckiej ${ }^{45}$.

\footnotetext{
${ }^{40}$ Por. 282 KPK.

${ }^{41}$ Warto w tym miejscu zauważyć, że w świetle art. 97-99 Statutów III Synodu Archidiecezji Łódzkiej strojem duchownego jest sutanna lub tzw. strój krótki. Sutanna obowiązuje przy wszystkich czynnościach liturgicznych, w kancelarii, na katechezie, podczas wszelkich uroczystości religijnych i w czasie występowania w charakterze urzędowym. Strój krótki, składający się z czarnego garnituru i koloratki, może być używany poza wypadkami wyżej wymienionymi (por. Statuty art. 97-99).

${ }^{42}$ Por. kan. 283, 284, $287 \$ 1$ KPK.

${ }^{43}$ Por. kan. $285 \$ 1$ KPK. III Synod Archidiecezji Łódzkiej stwierdza: „Kapłanom zabrania się przyjmowania urzędów, z którymi łączy się sprawowanie władzy świeckiej, jak również brania czynnego udziału w działalności partii politycznych, chyba że obrona praw Kościoła lub dobra wspólnego będą wymagały bezpośredniego zaangażowania w tego typu działania. Na takie działania duchowni muszą mieć wyraźne zezwolenie Arcybiskupa" (Statuty, art. 125).

${ }^{44}$ Por. kan. $285 \$ 1$ KPK.

${ }^{45}$ Por. kan. $285 \$ \$ 2-3$ KPK; Sacra Congregatio pro Cleris, Declaratio Quidam episcopi, de quibusdam associationibus vel coadunationibus quae omnibus clericis prohibentur, 8 martii 1982, AAS 74, 1982, s. 642-645.
} 
Kapłanowi wolno jedynie za zezwoleniem własnego ordynariusza podejmować zarząd dóbr osób świeckich, wykonywać świeckie urzędy, z którymi łączy się obowiązek składania rachunków, podpisywać weksle i poręczenia nawet własnym majątkiem ${ }^{46}$, uprawiać handel ${ }^{47}$ oraz zaciągać się dobrowolnie do wojska ${ }^{48}$.

\section{Wnioski}

Prawodawca stwierdza, że wyświęcić można tylko tego, kto cieszy się należytą wolnością. Akt przyjęcia święceń winien być zatem świadomy i dobrowolny. Oznacza to, że jako taki wymaga wolności w sensie psychologicznym, w takim stopniu, by osoba przyjmująca świecęnia znała przedmiot swoich zobowiązań i mogła nim dysponować.

W strukturze aktu przyjęcia świeceń wyróżnia się cztery podstawowe elementy. Są nimi: motywacja, osąd, wybór i realizacja podjętej decyzji. Motywacja wskazuje faktory i przyczyny, które decydują o podjęciu konkretnej decyzji. Osąd oparty na poznaniu oceniającym formułuje konkretne sugestie rozwiązań i ocenę poszczególnych możliwości. Decyzja, czyli wybór dokonany w sposób wolny jest w ścisłym tego słowa znaczeniu aktem woli wybierającej stan kapłański. Wypełnienie decyzji jest jedynie uzupełnieniem aktu woli.

Akt przyjęcia święceń jako akt ludzki, a jednocześnie o charakterze psychicznym, wymaga od kandydata zdolności psychicznej koniecznej do jego wyrażenia. Zdolność ta oznacza, iż dana osoba w momencie przyjmowania święceń jest zdolna powziąć decyzję dotyczącą życia kapłańskiego w sposób świadomy i dobrowolny oraz jest zdolna wypełnić wynikające ze święceń zobowiązania. W konsekwencji brak tej zdolności oznacza niezdolność naturalną do przyjęcia święceń, czyli brak należytej wolności, o której mowa w kan. 1026 KPK.

\footnotetext{
${ }^{46}$ Por. kan. $285 \$ 4$ KPK.

${ }^{47}$ Por. kan. 286 KPK.

${ }^{48}$ Por. kan. $289 \$ 1 \mathrm{KPK}$.
} 


\section{Concept of due freedom necessary for the reception of ordination}

The act of receving ordination as a human act requires the canididate to have the mental capacity necessary to express it. This ability means that a person, at the time of ordination, is able to make a conscious and voluntary decision about priestly life and is able to fulfill the obligations arising from ordination. Consequently, the lack of this capacity means a natural incapacity to receive orders, a lack of the due freedom mentioned in can. 1026 of the CIC.

SŁOWA KLUCzowE: święcenia; wolność; akt ludzki; zdolność psychiczna

KEYWORDS: ordination; freedom; human act; mental capacity

\section{NOTA O AUTORZE}

Ks. PROF. DR hAB. Grzegorz LeszczyŃski - profesor na Wydziale Prawa i Administracji Uniwersytetu Łódzkiego, Oficjał Trybunału Archidiecezji Łódzkiej. 